\title{
Experimental Analysis of Gas Split Injection Effect on Dual-Fuel Engine Performance
}

\author{
Semin $^{1}$, Yudha Prasetiyo ${ }^{2}$, Beny Cahyono ${ }^{3}$, Frengki Mohamad Felayati ${ }^{4}$ \\ (Received: 02 August 2019 / Revised: 26 February 2021 / Accepted: 03 March 2021)
}

\begin{abstract}
However, in dual-fuel engine operations, problems occur in low-load operations. The combustion quality with unstable combustion conditions and relatively low thermal efficiency. In this research, a gas split injection strategy was implemented on the dual-fuel engine. The purpose of this research is to compare the performance of the engine between dual-fuel operations using gas split injection strategy and single injection. Furthermore, split injection is a fuel injection system by dividing the injection into several injection stages with a certain mass and period. This injection system was applied on a dual-fuel engine system, which was previously a modification of the conventional diesel Yanmar TF $85 \mathrm{MH}$. The variation in this study is the injection split ratio (ISR) 75-25, variations in injection time, and variations in load with specified engine speed at 2000 RPM. The results obtained in this study are the best variations found in ISR 75-25 gas split injection with injection distance at $260^{\circ}$ bTDC \& $244^{\circ}$ bTDC. Due to the injection distance, a significant difference occurred in all parameters tested between single injection and split injection. The significance of the difference in power, torque, BMEP, SFOC, and the thermal efficiency only occurs at $100 \%$ load, which is $4.3 \% ; 4.2 \% ; 4.2 \% ; 16 \% ; 18.3 \%$.
\end{abstract}

Keywords—diesel, dual-fuel engine, gas split injection, injection split ratio, performance.

\section{INTRODUCTION}

$\mathrm{I}$ In this era of industries, the diesel engine is widely used in the commercial sector, like in transportation, automotive, industrial sector, and other sectors. The reason for this is considering diesel engines is because it has a fuel conversion efficiency and is easy to maintain [1]. There has been a lot of research and development to occur in diesel engines. Some of these technologies have been researched to develop the more high performance of the diesel engine is the use of fuels other than diesel fuel has been agreed to see how they affect performance and efficiency.

Natural gas (NG) is a very useful and appealing transportation fuel because of its availability, low cost, and good quality [2]. NG is utilized in a variety of industrial applications. It is expected that the adoption of NG will boost production and economic value. On the creation of dual-fuel engines based on the future development of gasoline engines, diesel engines, and also gas-fueled engines [3].

Compressed natural gas (CNG) is a type of fuel that has long been utilized in diesel engines, notably in transportation equipment development [4]. The use of an engine that runs on compressed natural gas provides both economic and environmental benefits. Overpressure methane gas was used to create CNG. The most common

Semin, Department of Marine Engineering, Institut Teknologi Sepuluh Nopember, Surabaya 60111, Indonesia, Email semin@its.ac.id

Yudha Prasetiyo, Department of Marine Engineering Institut Teknologi Sepuluh Nopember, Surabaya 60111, Indonesia, Email : yudhaprasetiyo14@gmail.com

Beny Cahyono, Department of Marine Engineering, Institut Teknologi Sepuluh Nopember, Surabaya 60111, Indonesia, Email : benyjtsp98@gmail.com

Frengki Mohamad Felayati, Department of Marine Engineering, Institut Teknologi Sepuluh Nopember, Surabaya 60111, Indonesia, Email : frengki11@mhs.ne.its.ac.id basic substance of the CNG is methane gas. CNG should be stored and distributed with standard pressure of 20-25 MPa for safety [5].

Natural gas is a hydrocarbon derivative with a simple composition, CNG has a high octane number content, which is typically utilized for a specialized engine with a high RPM need [6]. As a result, during combustion, CNG fuel has an impact on engine performance. CNG also provides advantages, including having a low impact on greenhouse gas emissions and producing cleaner exhaust gas.

If the dual-fuel engine is modified in its operating state, it can run on diesel systems or a combination of NG and diesel. The NG fuel is injected together with the air mixes that occur when air enters the system [5]. The dual-fuel engine system, in which NG is injected into the cylinder along with airflow shortly before the compression stroke is completed [7]. As an increase for the CNG and air mixture process, a valve is required which regulates the pressure on CNG spray, thus providing a strategy for injection, making injection systems and can improve the condition of gas-air fuel mixtures [8].

The heat flow peak at the dual-fuel engine has a high value if the combustion duration is short and the flow of fuel flows lower than the internal combustion engine [9]. The peak heat release of the flow affects the combustion value, from the fuel at the time of being ignited. The air mixture combustion affects the quality of the combustion value itself. The peak point of combustion on fuel affects the results of engine performance.

Natural gas and diesel are two different types of fuel that have a different composition too. The combustion that occurs at the diesel inside the cylinder is combustion controlled by flow and mixing of mist fuel with air [2]. Diffusion combustion here is a mixture of combustion air 


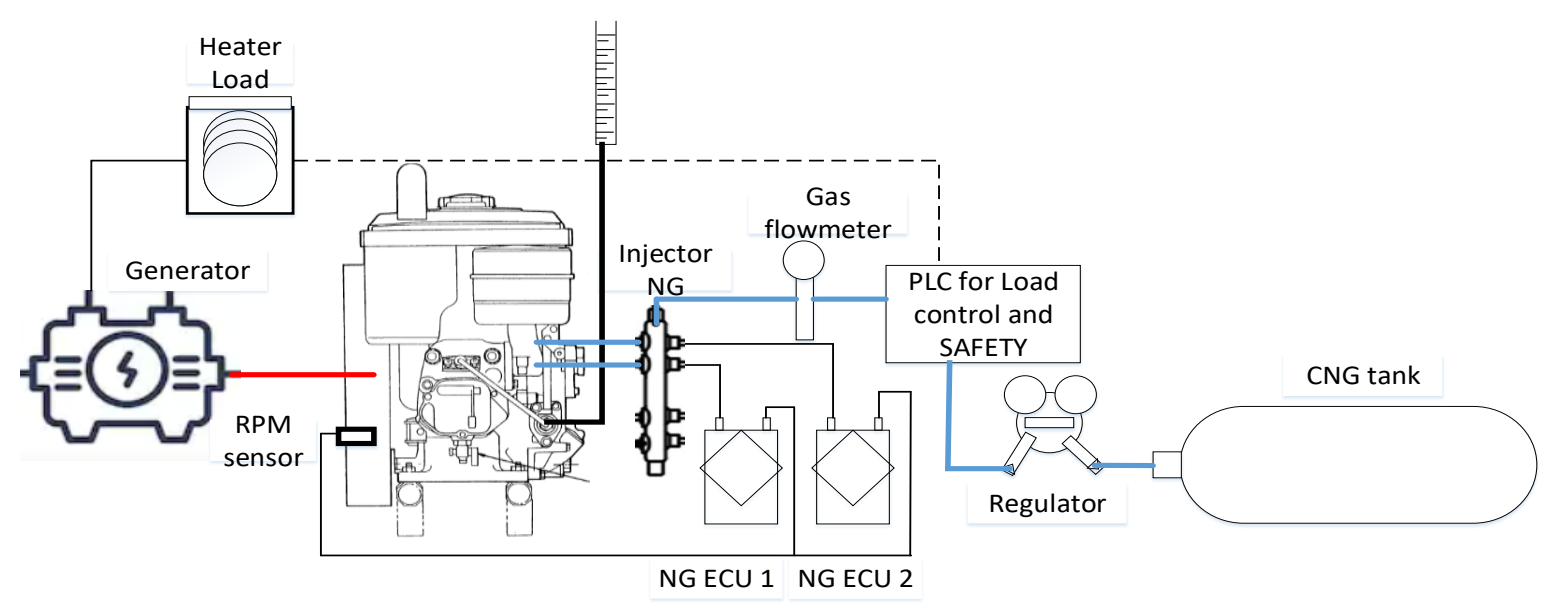

Figure. 1. Diagram dual fuel gas split injection experimental set-up.

and fuel used for the combustion process. The mixing of diesel and CNG, each other of them could influence the combustion results. The turbulent flow in the combustion chamber that an effect on the combustion process which results in improved engine performance [10].

In the injection process, the delays are given, as well as the split injection. in that phenomenon, injection is divided into two several injection zones to control fuel equalization. it can reduce the burning period although the ignition delay becomes longer [11].

The combustion could be trouble if the fuel does not burn completely the condition occurs, the methane gas can be an increase possible of the "greenhouse effect". The dual-fuel engine is the main method for flowing fuel to the injection line on natural gas, which is making a fuel-water premix mixture [12]. The dual-fuel engine mode is proven to improve performance and emissions aspects, but on the other hand, it has a problem with low loads [13]. Efficiency could be decrease compared to conventional diesel engines at low load operations. The low load condition was caused by unburned hydrocarbons in the fuel in the combustion process [2].

The split injection on diesel is used to improve the quality of combustion. Split injection strategy is a strategy for changing the characteristics of pressure in the injection, timing at the injection, and time interval for injection [14]. The split injection is a strategy to control the supply of fuel injected into the cylinder for the combustion process. The results show that split or multiple injections affect increasing air-fuel mixtures and reducing air/fuel mixture concentrations [15]. Furthermore, the split injection can also significantly reduce NOx formation compared to sustainable fuel injection [16].

If comparing with ISR 1.0 injection, which is a single injection, the split injection can produce higher IMEP values and lower emissions [17]. The mass distribution of NG and fuel mixture when the split injection that the result, combustion with a shorter ignition delay [18]. This strategy could have high flexibility to be able to effectively control the characteristics of combustion results. In split injection, an increase in performance is possible because of the injection distance that occurs between the initial combustion and the subsequent injection that follows [19]. Therefore, this strategy results in injection distance which results in increased performance. Furthermore, the injection affects the fuel mixture with air.

The homogeneity of the fuel-air mixture is influenced by the circumstances in the combustion chamber. A split injection approach is utilized to manage the conditions in the combustion chamber [20]. The air-fuel mixture is the factor that must be taken into account while determining the combustion characteristics in the combustion chamber. Each property employed in the combustion process, from the amount of fuel to the amount of air, is measured. Split Injection allows us to manage the amount of fuel and pressure that enters the combustion chamber. This study, on the other hand, looked at the influence of gas split injection on performance by varying the Injection Split Ratio (ISR).

\section{METHOD}

Figure 1 shows a schematic diagram of the singlecylinder diesel engine modification with gas split injection strategy used in this research to analyze the effect that occurs if compare the performance of the engine between dual fuel operations without the gas split injection strategy and dual-fuel engine operation with the gas split injection strategy. The main features of the diesel engine used in this research are natural airflow, the compression ratio of 18 , bore/stroke size of $85 \mathrm{~mm} / 87$ $\mathrm{mm}$, and displacement volume of $493 \mathrm{~cm}$. The fuelinjected at 18 (before top dead center) bTDC injection timing, and pressure at $200 \mathrm{~kg} / \mathrm{cm} 3$. A detailed engine specification showed in Table 1.

An engine modification of Yanmar TF-85 MH used fuel injected gas control as a control to data measurement variables such as injection timing, injection distance, injection quantity. By using the VemsTune program, the electronic control unit (ECU), controls the gas injection parameters in gas manifolds. The use of VemsTune a setting in Table 2. 
TABLE 1 .

ENGINE SPECIFICATION

\begin{tabular}{ll}
\hline Item & Specification \\
\hline Engine Series (four-stroke cycle) & $:$ Yanmar TF $85 \mathrm{MH}$ \\
Num of cylinders & $: 1$ \\
Combustion system (Injection type) & $:$ Direct Injection \\
Bore x stroke & $: 85 \mathrm{~mm}$ x $87 \mathrm{~mm}$ \\
Displacement & $: 493 \mathrm{cc}$ \\
Compression ratio (CR) & $: 18: 1$ \\
Injection timing & $: 18^{\circ} \mathrm{bTDC}$ \\
Pressure of injection & $: 200 \mathrm{~kg} / \mathrm{cm} 3$ \\
Max. Engine RPM at full load & $: 2200 \mathrm{RPM}$ \\
Continuous power output & $: 7.5 \mathrm{~kW}$ \\
Specific fuel oil consumption & $: 229.31 \mathrm{gr} / \mathrm{kWh}$ \\
\hline
\end{tabular}

Preparation of supporting instruments and instruments as supporting facilities for measurement in dual-fuel gas split injection research has been prepared. The instrument includes measuring instruments and sensors. The deduction instrument in this research scheme is divided into several parts. The first part is the lane scheme for CNG fuel and the second part is the lane scheme for diesel fuel.
Additional devices were required to record and accept parameters that were noticed as measuring instruments and sensors. The utilization of these enhancements is a piece of extension equipment from the gas split injection strategy's modified Yanmar TF-85 MH engine. The improvements include a sensor that able to read the RPM, a flowmeter to read the gas flow, and a pressure gauge to measure the pressure of the gas.

TABLE 2 .

VEMSTUNE SETTING COMBINATION FOR GAS INJECTION

\begin{tabular}{cccc}
\multicolumn{4}{c}{ VEMSTUNE SETTING COMBINATION FOR GAS INJECTION } \\
\hline Load (\%) & $\begin{array}{c}\text { VemsTune Setting for } \\
\text { Gas Split injection (ms) } \\
\text { VemsTune Setting for } \\
\text { Single Injection (ms) }\end{array}$ & \multicolumn{2}{c}{ Split 75:25 } \\
\hline $25 \%$ & 8 & ECU 1 & ECU 2 \\
\hline $50 \%$ & 9.5 & 5.5 & 0.5 \\
$75 \%$ & 10.5 & 6.5 & 1 \\
$100 \%$ & 12 & 7.5 & 1.5 \\
\hline
\end{tabular}

In addition, the engine settings worked in standard diesel, dual fuel, and also dual-fuel gas split injection modes. Gas is injected into the system through the intake air. The gas injector manifold is mounted as close to the air intake inlet as possible. Two electronic control units (ECUs) regulate both first and second injectors in the gas injector manifold.

The PLC is required for load control and safety reason. The engine is connected to a generator, which produces electrical power that is utilized to load the heater at several levels of load: $25 \%, 50 \%, 75 \%$, and $100 \%$. The time at which diesel fuel consumption is parallel with CNG consumption using a gas flow meter is determined by reading the consumption of diesel fuel at the measuring cylinder.

TABLE 3.

EXPERIMENTAL SET-UP VARIATION

\begin{tabular}{ccccc} 
Mode & $\begin{array}{c}\text { Engine } \\
\text { rotation } \\
(\text { RPM) }\end{array}$ & $\begin{array}{c}\text { First Injection } \\
\%\end{array}$ & $\begin{array}{c}\text { Second } \\
\text { Injection \% }\end{array}$ & $\begin{array}{c}\text { Crank angle gas } \\
\text { injection ('bTDC) }\end{array}$ \\
\hline \multirow{3}{*}{ Single-injection } & 1800 & & & \\
& 1900 & & & \\
& 2000 & 100 & & 260 \\
& 2100 & & 260 & 244 \\
Gas split injection & 2200 & & & 130 \\
\hline
\end{tabular}

The variation setting injection split ratio (ISR) in Table 3 is the injection setting for the gas supply. The ratio in the table is the ratio based on the length of injection to supply the gas flow of time (ms). As a parameter for various settings, the injection split ratio serves as the basis for taking data for each of the different settings in Table 3. Previously, the variation obtains for the length of injection time and req fuel in $\mathrm{ms}$ units.

In comparison to the dual-fuel system for single injection, there is a difference in the injection system when using a dual-fuel engine with a gas split injection 
strategy. This technique employs a stepwise infusion scheme with a predefined ratio. That is, for one combustion cycle, there are multiple injections with a predetermined injection length and injection duration.

When this method is followed, the CNG in the air intake port is gradually injected. It is expected to be able to provide a uniform distribution of CNG mixes in the combustion chamber with greater air compression. At one CNG injection, the CNG mass in the air combined with CNG is the same as under dual-fuel situations. The same injection mass achieves dual fuel conditions at one time CNG injection according to the combination of gas manifold parameters that are offered.

The gas split injection approach, like a one-time dualfuel injection system, necessitates engine rotation under diesel operating circumstances initially. The gas split injection mechanism is then activated after the engine has reached a steady-state at the appropriate engine speed. CNG is still injected through the intake port. To do a split injection technique, it only gave two CNG entry locations.

Following the activation of the split injection system, the operation of traditional diesel engines as an operational prefix has changed. The activation of the split injection system takes place first in a conventional diesel system. In standard diesel settings, the results of this method result in a higher steady-state engine speed. When the speed of the machine increases, so does its performance. Additionally, the diesel throttle is reduced in this condition so that the engine speed matches the initial steady-state circumstances. Because CNG is being used to replace the diesel fuel throttle, consumption of diesel has decreased. Consumption reduced in the end, but the outcomes were positive. Diesel consumption has decreased as a result of $\mathrm{CNG}$ being used to replace the diesel fuel throttle being reduced. In the end, the consumption was reduced, but the power obtained was enhanced.

\section{RESULTS AND DISCUSSION}

\section{A. Performance of dual-fuel with a gas single injection}

Dual fuel engine performance with a gas single injection in this experiment observes for several parameters ranging from power, torque, BMEP, SFOC, eff thermal. These parameters are obtained from data processing in the graph of the data processing results. Data taken is operating dual-fuel engines on $260^{\circ}$ bTDC injection timing. Retrieval of the data at engine speed 1800-2200 RPM with the condition of the engine has been modified dual fuel mode.

The input data is processed for the results of the parameters obtained in the form of engine speed, generator rotation, $\mathrm{CNG}$ flow quantity, the voltage on the generator according to load, current on the generator according to load, liquid fuel consumption, and fuel gas consumption. Furthermore, the data process becomes a graph for each load that charged to the engine when the performance test. As shown in Table 2 of the VemsTune setting for the dual fuel section, the settings input on VemsTune used for CNG manifold set-up. The combination in Table 2 is an optimum combination for the injection time and duration of openings in the condition of a dual-fuel gas single injection.

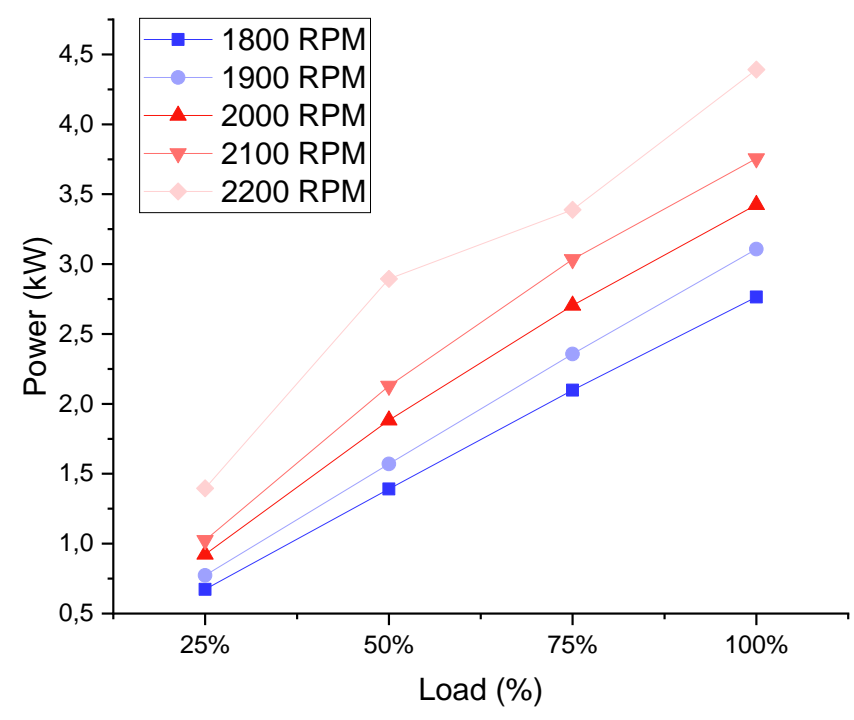

Figure. 2. Comparison of load and power on dual fuel.

Figure 2 was obtained by mapping the dual engine fuel with the injection time $\left(260^{\circ} \mathrm{bTDC}\right)$. From the dualfuel engine operation, the greater the trend of load loading, the greater the power produced to meet the load requirements of the generator. In the graph, the lowest power at $1800 \mathrm{RPM}=0.672 \mathrm{~kW}$, and the highest power at engine speed is $2200 \mathrm{RPM}=4.391 \mathrm{~kW}$. It observed that Figure 2, the graph of each engine rotation for load 
produces a power that has a good trend, which is deviation in round 2200 occurs, which is a load of $75 \%$. increasing. The mapping on the dual-fuel engine has been obtained for the power parameters. Only a

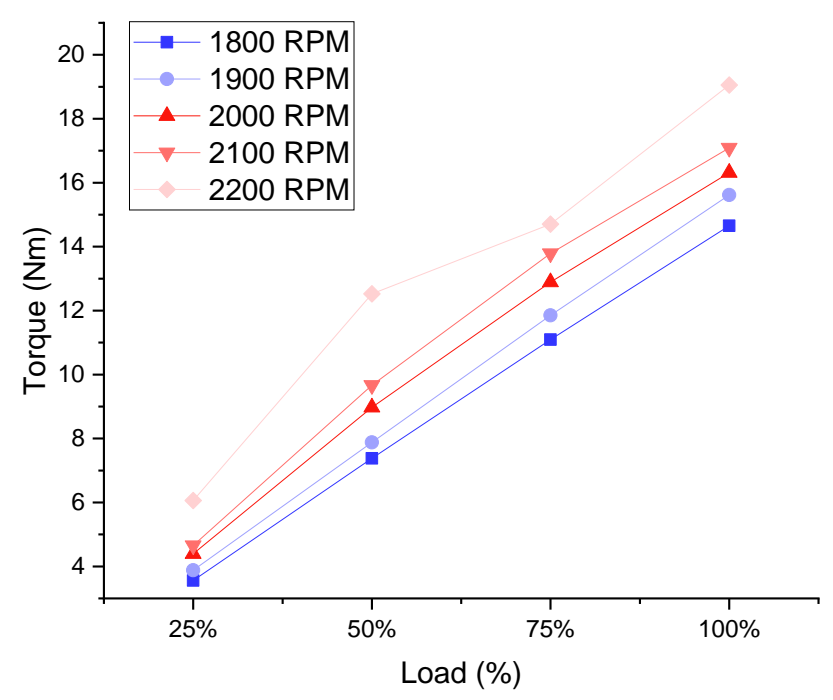

Figure. 3. Comparison of load and torque on dual fuel.

Figure 3 can show a torque mapping according to each load given at the operational engine rotation as explained before. Following the power value compared to the load, the torque value can fluctuate according to the load of the load given. The data obtained, the lowest torque value occurs at 1800 RPM engine speed and loads $25 \%$ which is $=3,559 \mathrm{Nm}$ and the highest occurs in the engine 2200 RPM and load 100\% which is $=19.05 \mathrm{Nm}$. The data obtained is relatively following the uptrend, but anomalies occur again like load data on power. The load of $75 \%$ and an engine speed of 2200 RPM, but the mapping of the torque can lead to the conclusion that the greater the load is given, the greater the torque produced.

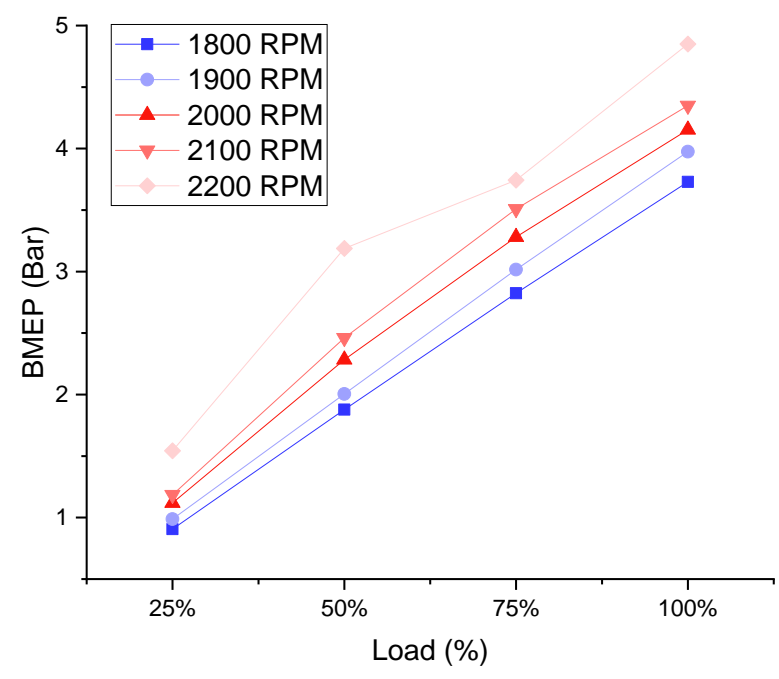

Figure. 4. Comparison of load and BMEP on dual fuel.

Based on Figure 4 of the graph, it is observed that given the increase in load that results in higher BMEP values. The BMEP value obtained is the data at each engine rotation following the operations mentioned before. With a load of $25 \%$ to $100 \%$, it is known the trends that occur.

The lowest BMEP value obtained at engine speed 1800 RPM and a load of $25 \%$ of 0.91 Bar. While the highest data obtained at an engine speed of 2200 RPM at a load of $100 \%$. The trend is the same for each engine speed, but there is an anomaly back at the engine speed of 2200 RPM with a load of $75 \%$. These results are a mapping of the engine that produces characteristics of the dual-fuel engine operation. 


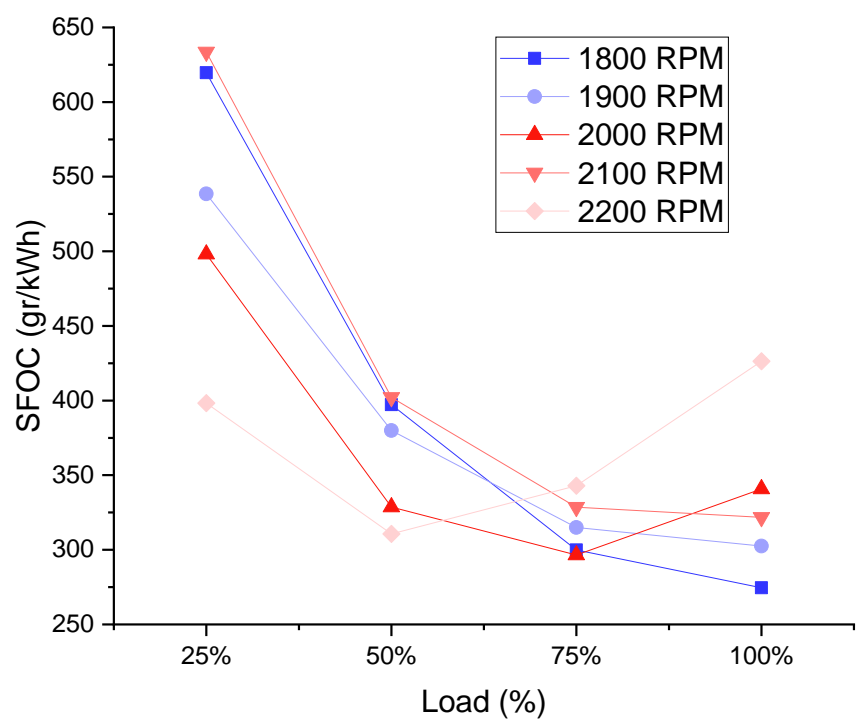

Figure. 5. Comparison of load and SFOC on dual fuel.

In Figure 5, a graph of load processing is compared with SFOC. The trend obtained is, the greater the load that is given, the consumption value can decrease but it can increase at high load. The SFOC values presented are SFOC values based on loads charged to machines ranging from $25 \%, 50 \%, 75 \%$, and $100 \%$.

The tendency of the air to decline and then increase again is a characteristic obtained from dual-fuel engine operations after mapping SFOC data. The data is a reference for the optimum rotation of the engine. The trend of optimum SFOC values obtained at engine speed 2000 RPM that the rotation that we assume is the optimum rotation according to the operational characteristics of dual-fuel engines.

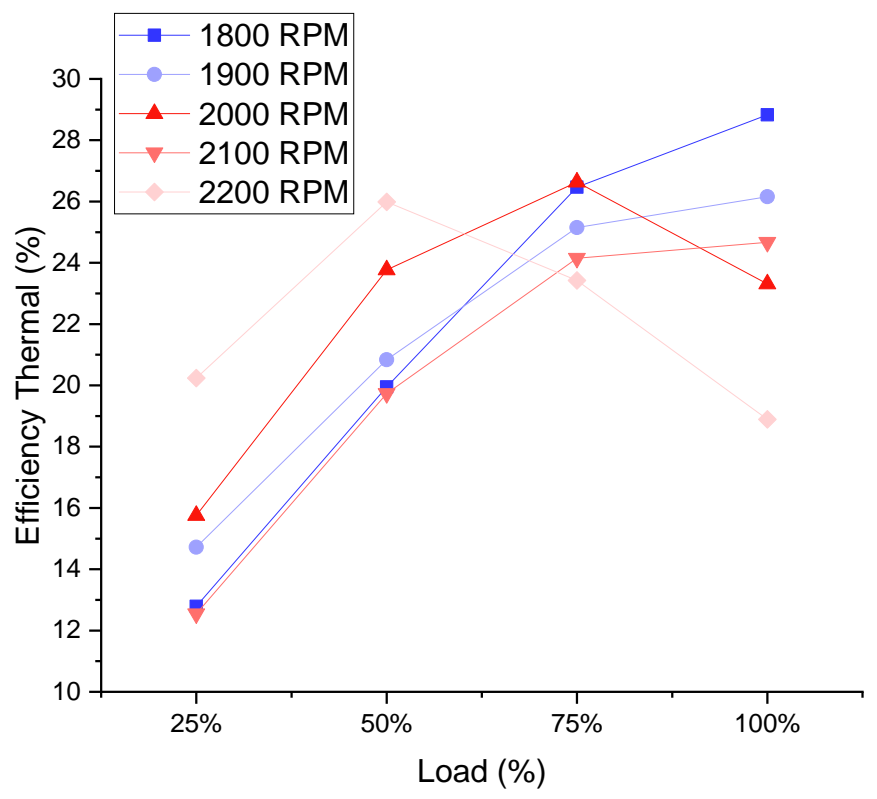

Figure. 6. Comparison of load and efficiency thermal on dual fuel.

Figure 6 is a graph of the comparison of load compared with thermal efficiency observed. The results of his observations, namely the value of thermal efficiency tend to fluctuate up then a decrease at a high load. This trend is characteristic of the dual-fuel engine obtained in this experiment. The mapping of thermal efficiency obtained can produce a tendency according to the operational characteristics of dual-fuel engines.

The highest thermal efficiency obtained at engine speed
1800 RPM at a load of $100 \%$. The decrease in thermal efficiency occurs at engine speed 2000 RPM with an anomaly of a significant decrease in high load. Anomaly is possible because the high load of heat is more wasted and the energy used decreases because it has reached the optimum point of engine operation at engine speed 2000 RPM.

B. Gas Split Injection Effect on Engine Performance 
Data retrieval with ISR 75-25 configuration on VemsTune by dividing gas fuel injection by $75 \%$ \& $25 \%$ on single injection dual-fuel. Setting input at each Electronic Control Unit (ECU). Certain settings for the ECU in split mode are adjusted by single injection on dual-fuel mode.

Setting the injector crank angle for the first variation of ECU 1 with the RPM used 2000 RPM is set at $260^{\circ} \mathrm{bTDC}$ and ECU 2 set at $230^{\circ} \mathrm{bTDC}$ with the RPM used 2000 RPM. In the second variation of ECU 1 with the RPM used 2000 RPM set at $260^{\circ}$ bTDC and ECU 2 with the RPM used 2000 RPM set at $244^{\circ}$ bTDC. The arrangement is intended as an injection delay in natural gas injection.

VemsTune performs according to the combination. Intended to have an optimum split strategy on dual fuel operations. The combination tested for several trials with a small difference in margin data.

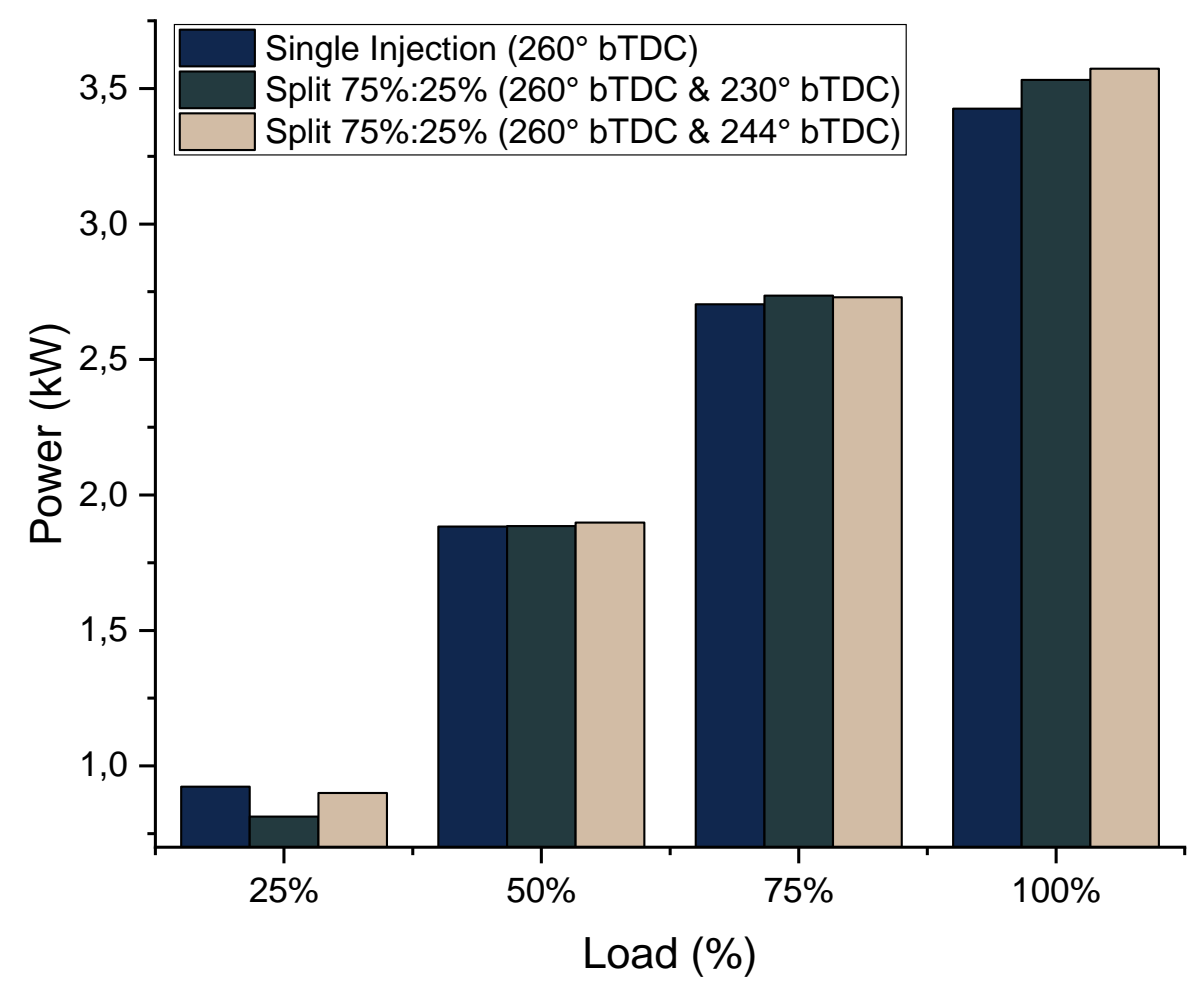

Figure. 7. Comparison of load and power at 75-25 split.

TABLE 3.

COMPARISON SINGLE INJECTION AND SPLIT INJECTION

\begin{tabular}{cccccc}
\hline & $\begin{array}{c}\text { (A).Single } \\
\text { Injection }\end{array}$ & $\begin{array}{c}\text { (B). Split } \\
\left(260^{\circ} \&\right. \\
\left.230^{\circ}\right)\end{array}$ & $\begin{array}{c}\text { (C). Split } \\
\left(260^{\circ} \&\right. \\
\left.244^{\circ}\right)\end{array}$ & $\begin{array}{c}\text { (B) against } \\
(\mathrm{A})\end{array}$ & $\begin{array}{c}\text { (C) against } \\
\text { (A) }\end{array}$ \\
& & & & \multicolumn{2}{c}{ Percentage $(\%)$} \\
Load & & Power $(\mathrm{kW})$ & & -11.96 & -2.47 \\
\hline $25 \%$ & 0.92 & 0.81 & 0.90 & 0.10 & 0.82 \\
$50 \%$ & 1.88 & 1.88 & 1.90 & 1.18 & 0.95 \\
$75 \%$ & 2.70 & 2.74 & 2.73 & 3.11 & 4.32 \\
$100 \%$ & 3.43 & 3.53 & 3.57 & & \\
\hline
\end{tabular}

From the processing of the data that the resulting graph in Figure 7 observed, the dual-fuel gas split injection strategy can increase the power value. Table 3, shows the percentage increase obtained with a value of $0.1 \%$ to $4.3 \%$. The $0.1 \%$ increase is obtained at a $50 \%$ load and split 75-25 dual-fuel configuration (260 bTDC $\left.\& 230^{\circ} \mathrm{bTDC}\right)=1,884 \mathrm{~kW}$ and dual-fuel $\left(260^{\circ} \mathrm{bTDC}\right)$ $1,883 \mathrm{~kW}$ and a $4.3 \%$ increase in $100 \%$ load and split 75-25 dual-fuel configuration $\left(260^{\circ} \mathrm{bTDC} \& 244^{\circ} \mathrm{bTDC}\right.$ )$=3.57 \mathrm{~kW}$ and dual-fuel $\left(260^{\circ} \mathrm{bTDC}\right)=3.43 \mathrm{kWh}$. Based on this increase, the gas split injection strategy succeeded in increasing the value of power.
The power increase that occurs in the split injection gas strategy can occur due to the gradual injection of more uniform air-fuel mixing compared to injection which occurs only once on a dual-fuel system. The injection can have a better combustion effect. The power can increase as shown in Figure 7. 


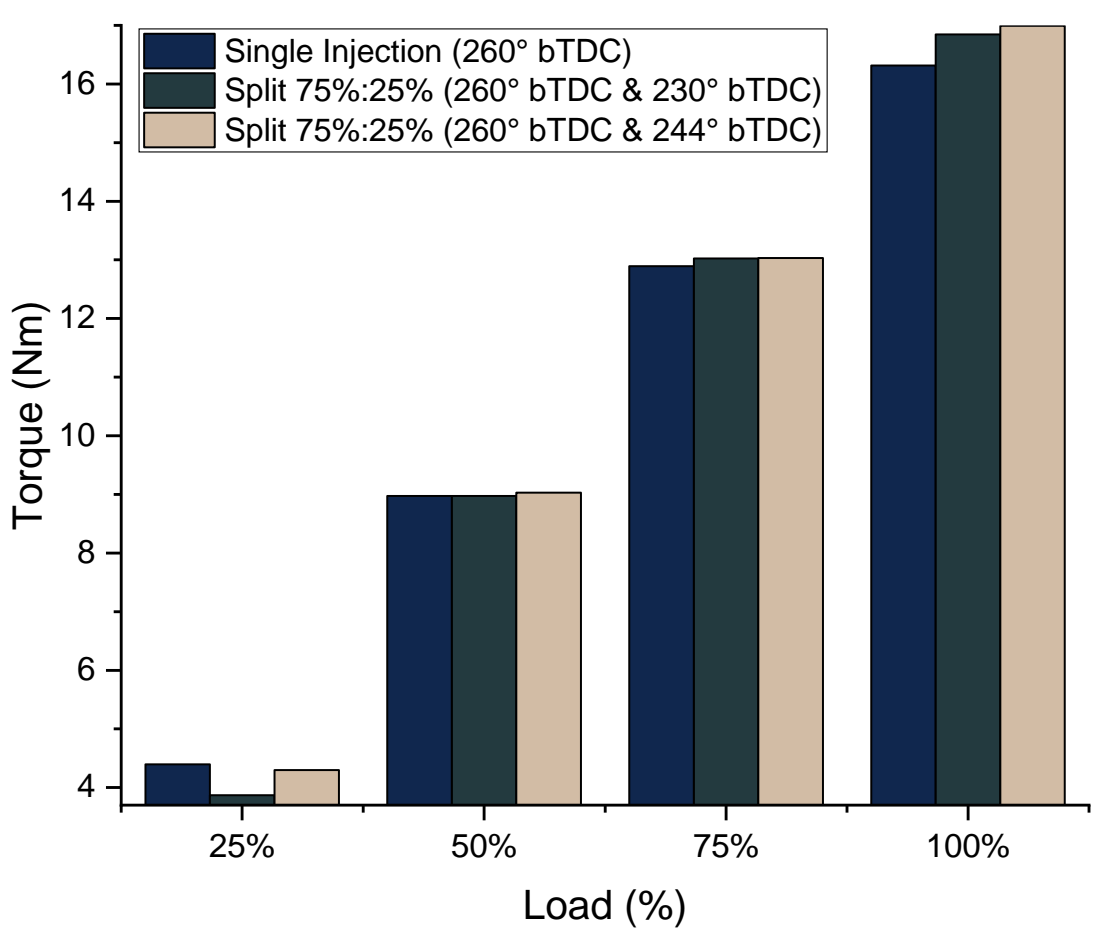

Figure. 8. Comparison of load and torque at 75-25 split.

TABLE 4.

COMPARISON SINGLE INJECTION AND SPLIT INJECTION

\begin{tabular}{cccccc}
\hline & $\begin{array}{c}\text { (A).Single } \\
\text { Injection }\end{array}$ & $\begin{array}{c}\text { (B). Split } \\
\left(260^{\circ} \&\right. \\
\left.230^{\circ}\right)\end{array}$ & $\begin{array}{c}\text { (C). Split } \\
\left(260^{\circ} \&\right. \\
\left.244^{\circ}\right)\end{array}$ & $\begin{array}{c}\text { (B) } \\
\text { against } \\
\text { (A) }\end{array}$ & $\begin{array}{c}\text { (C) against } \\
\text { (A) }\end{array}$ \\
& & & & \multicolumn{2}{c}{ Percentage (\%) } \\
Load & & Torque (Nm) & & -11.96 & -2.17 \\
\hline $25 \%$ & 4.39 & 3.87 & 4.30 & 0.00 & 0.62 \\
$50 \%$ & 8.97 & 8.97 & 9.03 & 1.03 & 1.10 \\
$75 \%$ & 12.89 & 13.02 & 13.03 & \\
\hline
\end{tabular}

Figure 8 observes that the gas split injection strategy has an influence on the increase in engine torque based on the configuration variations mentioned earlier. Table 4 , shows the percentage increase in torque is $0.4 \%$ to $4.2 \%$. The $0.4 \%$ increase was obtained with a $50 \%$ load and split 75-25 dual-fuel configuration $\left(260^{\circ}\right.$ bTDC \& $\left.244^{\circ} \mathrm{bTDC}\right)=9,028 \mathrm{Nm}$ and dual-fuel single injection $\left(260^{\circ} \mathrm{bTDC}\right)=8.97 \mathrm{Nm}$. At the highest percentage $4.2 \%$ was obtained with a $100 \%$ load and split 75-25 dual-fuel configuration $\left(260^{\circ} \mathrm{bTDC} \& 244^{\circ} \mathrm{bTDC}\right)=16,993 \mathrm{Nm}$ and dual-fuel $\left(260^{\circ}\right.$ bTDC $)=16,314 \mathrm{Nm}$. The strategy gas split injection strategy can increase the torque value.

The increase in torque that occurs is also another factor in improving engine performance. As with increasing power, the increase in torque is also influenced by the same thing, which is due to gradual gas injection and resulting in better mixing than gas injection which is only once in a dual-fuel system. Finally, this strategy is one way to increase engine torque.

Figure 9 observes, there is an effect of the strategy of using the split injection strategy compared to the operational single injection dual fuel. Table 5, shows, percentage difference in BMEP obtained for the split injection strategy is $0.6 \%$ to $4.2 \%$. Obtained the lowest $0.6 \%$ increase in BMEP for a 50\% load with split 75-25 dual-fuel configuration $\left(260^{\circ} \mathrm{bTDC} \& 244^{\circ} \mathrm{bTDC}\right)=$ 2,298 Bar and dual-fuel $\left(260^{\circ} \mathrm{bTDC}\right)=2,284$ Bars. The highest increase of $4.2 \%$ in BMEP for $100 \%$ load with split 75-25 dual-fuel configuration $\left(260^{\circ}\right.$ bTDC \& $\left.244^{\circ} \mathrm{bTDC}\right)=4.325$ Bar and dual-fuel $\left(260^{\circ} \mathrm{bTDC}\right)=$ 4.152. The gas split injection strategy succeeded in increasing BMEP on dual-fuel engines. 


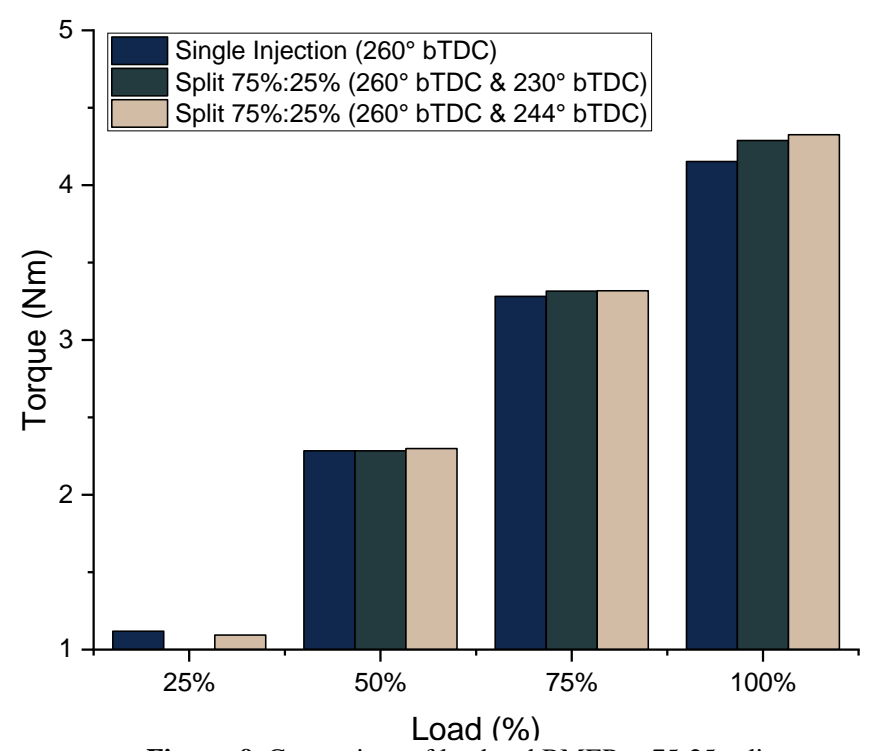

Figure. 9. Comparison of load and BMEP at 75-25 split.

TABLE 5 .

COMPARISON SINGLE INJECTION AND SPLIT INJECTION

\begin{tabular}{cccccc}
\hline & $\begin{array}{c}\text { (A).Single } \\
\text { Injection }\end{array}$ & $\begin{array}{c}\text { (B). Split } \\
\left(260^{\circ} \&\right. \\
\left.230^{\circ}\right)\end{array}$ & $\begin{array}{c}\text { (C). Split } \\
\left(260^{\circ} \&\right. \\
\left.244^{\circ}\right)\end{array}$ & $\begin{array}{c}\text { (B) } \\
\text { against } \\
(\mathrm{A})\end{array}$ & $\begin{array}{c}\text { (C) against } \\
(\mathrm{A})\end{array}$ \\
& & & & \multicolumn{2}{c}{ Percentage $(\%)$} \\
Load & & BMEP (Bar) & & -11.96 & -2.17 \\
$25 \%$ & 1.12 & 0.98 & 1.09 & 0.00 & 0.62 \\
$50 \%$ & 2.28 & 2.28 & 2.30 & 1.03 & 1.10 \\
$75 \%$ & 3.28 & 3.32 & 3.32 & \\
\hline
\end{tabular}

The increased value of BMEP resulting from the gas split injection strategy with an increase of $0.6 \%$ to $4.2 \%$, it caused by several things. The combustion characteristic factors are things that need to consider. Gradual combustion can occur then more heat is burned on the cylinder due to gas split injection by setting the injection distance [12].

Figure 10 observed the gas split injection strategy in dual-fuel reduce fuel consumption or reduce the SFOC value (gr / kWh). From the Table 6, show percentage of decrease with a value of $4.7 \%$ to $16 \%$. The reduction in

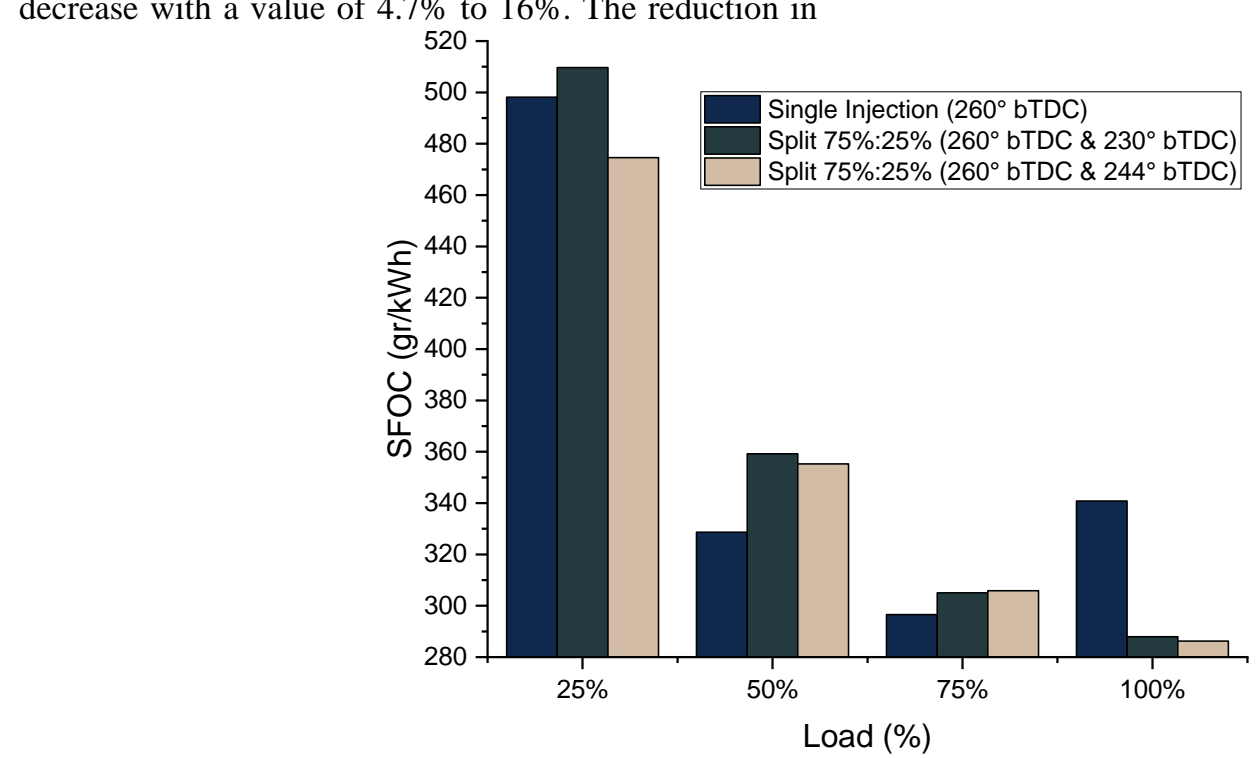

Figure. 10. Comparison of load and SFOC at 75-25 split.
SFOC of $4.7 \%$ at $25 \%$ load and split $75-25$ dual-fuel configuration $\left(260^{\circ} \mathrm{bTDC} \& 244^{\circ} \mathrm{bTDC}\right)=476.61 \mathrm{gr} /$ kwh and dual-fuel (260 $\left.{ }^{\circ} \mathrm{bTDC}\right) 498.13 \mathrm{gr} / \mathrm{kWh}$ and for decreasing $16 \%$ is obtained at 4000 loads and split $75-25$ dual-fuel configuration $\left(260^{\circ} \mathrm{bTDC} \& 244^{\circ} \mathrm{bTDC}\right)=$ $286,223 \mathrm{gr} / \mathrm{kwh}$ and dual-fuel (260 $\left.{ }^{\circ} \mathrm{bTDC}\right) 340,797 \mathrm{gr} /$ $\mathrm{kWh}$. Based on the decline, the gas split injection strategy succeeded in reducing fuel consumption (SFOC).

Figure. 10. Comparison of load and SFOC at $75-25$ split. 
TABLE 6.

COMPARISON SINGLE INJECTION AND SPLIT INJECTION

\begin{tabular}{|c|c|c|c|c|c|}
\hline & $\begin{array}{l}\text { (A).Single } \\
\text { Injection }\end{array}$ & $\begin{array}{c}\text { (B). Split } \\
\left(260^{\circ} \&\right. \\
\left.230^{\circ}\right)\end{array}$ & $\begin{array}{c}\text { (C). Split } \\
\left(260^{\circ} \&\right. \\
\left.244^{\circ}\right)\end{array}$ & $\begin{array}{c}\text { (B) } \\
\text { against } \\
\text { (A) }\end{array}$ & $\begin{array}{l}\text { (C) against } \\
\text { (A) }\end{array}$ \\
\hline Load & \multicolumn{3}{|c|}{ SFOC $(\mathrm{gr} / \mathrm{kWh})$} & \multicolumn{2}{|c|}{ Percentage $(\%)$} \\
\hline $25 \%$ & 498.14 & 509.66 & 474.61 & -2.31 & 4.72 \\
\hline $50 \%$ & 328.69 & 359.19 & 355.25 & -9.28 & -8.08 \\
\hline $75 \%$ & 296.56 & 305.01 & 305.87 & -2.85 & -3.14 \\
\hline
\end{tabular}

Decreasing the SFOC value in the gas split injection strategy is a good thing because it will be more efficient in consuming fuel consumption on the engine. The gas split injection strategy according to Figure 10 as a reference that the SFOC affects the strategy. Factors that affect this phenomenon include the gradual mixing of fuel then makes the air-fuel mixture better. So that the first injection of fuel will trigger the mixing of the second fuel [15].

In Figure 11 which is a graph of the comparison of load and thermal efficiency it can be observed that with the gas split injection strategy, an increase in thermal efficiency can occur. Percentage increase in thermal efficiency from $4.2 \%$ to $18.3 \%$. At a $4.2 \%$ increase occurred in a $25 \%$ load and split $75-25\left(260^{\circ}\right.$ bTDC \& $\left.244^{\circ} \mathrm{bTDC}\right)=16.412 \%$ and dual-fuel $\left(260^{\circ} \mathrm{bTDC}\right)=$
$15.753 \%$ while the $18.3 \%$ increase in percentage occurred in a 4000 load and split 75-25 dual-fuel configuration $\left(260^{\circ} \mathrm{bTDC} \& 244^{\circ} \mathrm{bTDC}\right)=27,576 \%$ and dual-fuel $\left(260^{\circ} \mathrm{bTDC}\right)=23.309 \%$. With this data it proved, the gas split injection strategy can improve thermal efficiency.

Increasing thermal efficiency in the strategic gas split injection is one of the things that is discussed in this study. This was proven by processing data that produce graphics. The increase in thermal efficiency is the effect of the gradual combustion in the cylinder, the phenomenon can increase the thermal efficiency of the engine [12]. At low loads a decrease in thermal efficiency. Because it was dominated by the premise of combustion due to the fuel being injected during the ignition delay [21].

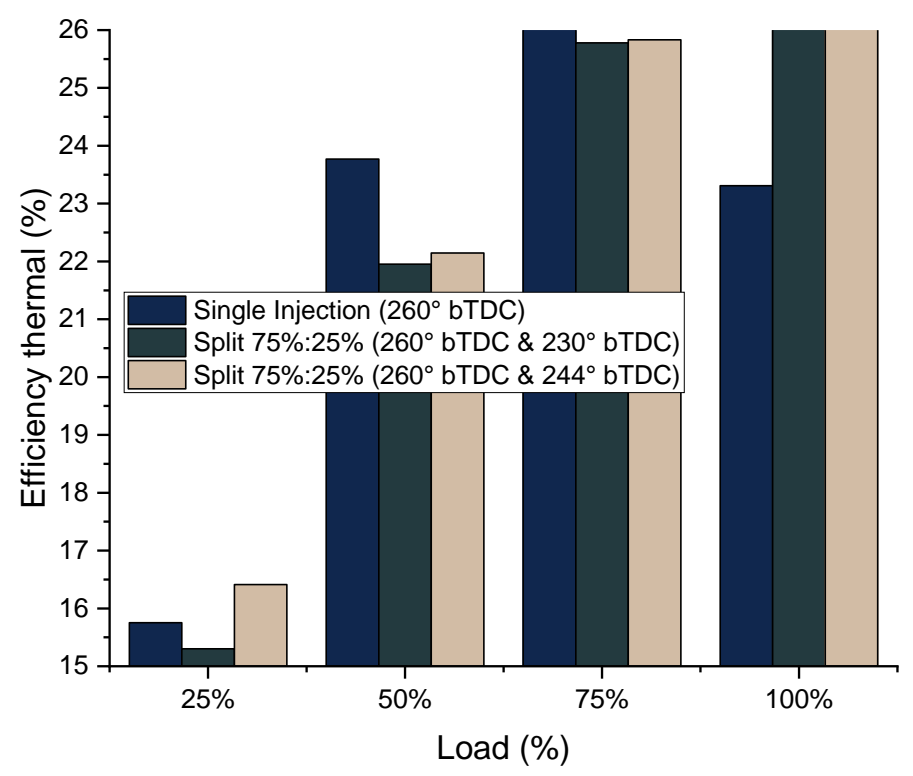

Figure. 11. Comparison of load and thermal efficiency at 75-25 split.

TABLE 7.

COMPARISON SINGLE INJECTION AND SPLIT INJECTION

$\begin{array}{lcccc}\text { (A).Single } & \text { (B). Split } & \text { (C). Split } & \text { (B) } & \text { (C) } \\ \text { Injection } & \left(260^{\circ} \&\right. & \left(260^{\circ} \&\right. & \text { against } & \text { against } \\ & \left.230^{\circ}\right) & \left.244^{\circ}\right) & \text { (A) } & \text { (A) }\end{array}$

\begin{tabular}{cccccc} 
Load & \multicolumn{3}{c}{ Thermal Efficiency $(\%)$} & \multicolumn{2}{c}{ Percentage $(\%)$} \\
\hline $25 \%$ & 15.75 & 15.30 & 16.41 & -2.87 & 4.18 \\
$50 \%$ & 23.77 & 21.95 & 22.15 & -7.65 & -6.83 \\
$75 \%$ & 26.63 & 25.78 & 25.83 & -3.19 & -3.00 \\
\hline
\end{tabular}




\section{CONCLUSION}

The results obtained in this study are the optimum variations found in ISR 75-25 gas split injection with injection distance at $260^{\circ} \mathrm{bTDC} \& 244^{\circ} \mathrm{bTDC}$. Due to the injection distance, the largest percentage difference occurred in all parameters tested between single injection and split injection. The greatest percentage of difference in power, torque, BMEP, SFOC, and thermal efficiency only occurs at $100 \%$ load, which is $4.3 \% ; 4.2 \%$; $4.2 \%$; $16 \% ; 18.3 \%$.

\section{REFERENCES}

[1] H. Bayraktar, "An experimental study on the performance parameters of an experimental $\mathrm{CI}$ engine fueled with dieselmethanol-dodecanol blends," Fuel, vol. 87, no. 2, pp. 158-164, 2008.

[2] L. Wei and P. Geng, "A review on natural gas/diesel dual-fuel combustion, emissions and performance," Fuel Process. Technol., vol. 142, pp. 264-278, 2016.

[3] Z. Wang et al., "Impact of pilot diesel ignition mode on combustion and emissions characteristics of a diesel/natural gas dual fuel heavy-duty engine," Fuel, vol. 167, pp. 248-256, 2016.

[4] Semin and R. A. Bakar, "A Technical Review of Compressed Natural Gas as an Alternative Fuel for Internal Combustion Engines," Am. J. Eng. Appl. Sci. 1, vol. 4, pp. 302-311, 2008.

[5] M. I. Khan, T. Yasmin, and A. Shakoor, "Technical overview of compressed natural gas (CNG) as a transportation fuel," Renew. Sustain. Energy Rev., vol. 51, pp. 785-797, 2015.

[6] K. Ryu, "Effects of pilot injection pressure on the combustion and emissions characteristics in a diesel engine using biodieselCNG dual fuel," Energy Convers. Manag., vol. 76, pp. 506-516, 2013.

[7] G. P. McTaggart-Cowan, S. N. Rogak, S. R. Munshi, P. G. Hill, and W. K. Bushe, "The influence of fuel composition on a heavy-duty, natural-gas direct-injection engine," Fuel, vol. 89, no. 3, pp. 752-759, 2010.

[8] Semin, N. S. Octaviani, A. P. Gusti, and M. B. Zaman, "Power Performance Characteristics Investigation of Gas Engine using New Injector," no. January 2016.

[9] J. Zheng, J. Wang, Z. Zhao, D. Wang, and Z. Huang, "Effect of equivalence ratio on combustion and emissions of a dual-fuel natural gas engine ignited with diesel," Appl. Therm. Eng., vol. 146, pp. 738-751, 2019.
[10] Semin, M. A. Satriawansyah, B. Cahyono, and N. S. Octaviani, "Analysis of Influence of Masks Flow on Intake Valve of Gas and Oil Fuel Engine Based Simulation," vol. 2, no. 3, pp. 225230, 2018.

[11] F. M. Felayati, B. Cahyono, and M. B. Zaman, "Improvement Approaches for the Combustion Process of Recent Diesel Natural Gas Dual Fuel Engines - A Technical Review," vol. 13, no. March, pp. 198-202, 2019.

[12] A. Yousefi, H. Guo, and M. Birouk, "An experimental and numerical study on diesel injection split of a natural gas/diesel dual-fuel engine at a low engine load," Fuel, vol. 212, no. October 2017, pp. 332-346, 2018.

[13] M. S. Lounici, K. Loubar, L. Tarabet, M. Balistrou, D. C. Niculescu, and M. Tazerout, "Towards improvement of natural gas-diesel dual fuel mode: An experimental investigation on performance and exhaust emissions," Energy, vol. 64, pp. 200211, 2014.

[14] S. Park, H. J. Kim, D. H. Shin, and J. T. Lee, "Effects of various split injection strategies on combustion and emissions characteristics in a single-cylinder diesel engine," Appl. Therm. Eng., vol. 140, no. September 2017, pp. 422-431, 2018.

[15] X. R. Li, H. Q. Zhou, L. M. Zhao, L. Su, H. Xu, and F. S. Liu, "Effect of split injections coupled with swirl on combustion performance in DI diesel engines," Energy Convers. Manag., vol. 129, pp. 180-188, 2016.

[16] S. D. Hiwase, S. Moorthy, H. Prasad, M. Dumpa, and R. M. Metkar, "Multidimensional modeling of direct injection diesel engine with split multiple stage fuel injections," Procedia Eng., vol. 51, pp. 670-675, 2013.

[17] Z. Wang, Y. Li, C. Wang, H. Xu, and M. Wyszynski L., "Nearnozzle microscopic characterization of diesel spray under cold start conditions with split injection strategy," Fuel, vol. 181, pp. 366-375, 2016.

[18] Z. Wang, H. Ding, X. Ma, H. Xu, and M. L. Wyszynski, "Ultrahigh speed imaging study of the diesel spray close to the injector tip at the initial opening stage with split injection," Appl. Energy, vol. 163, pp. 105-117, 2016.

[19] F. M. Felayati, Semin, and M. B. Zaman, "Consideration of split injection strategy for marine diesel engine combustion process," no. April, 2019.

[20] A. Jain, A. P. Singh, and A. K. Agarwal, "Effect of Split Fue Injection and EGR on NOx and PM Emission Reduction in a Low Temperature Combustion ( LTC ) Mode Diesel Engine," Energy, 2017.

[21] C. Y. Choi and R. D. Reitz, "An experimental study on the effects of oxygenated fuel blends and multiple injection strategies on DI diesel engine emissions," vol. 78, no. x, pp. 1303-1317, 1999. 